\title{
The contradictions of Lucas do Rio Verde - MT: The starting question to relate the category dignity of the human person and environment
}

DOI: $10.53499 /$ sfjeasv1n1-003

Received in: November 1st, 2020

Accepted in: December 30th, 2020

\author{
Mariele Schmidt Canabarro Quinteiro \\ Doutoranda em Política Social pela Universidade de Brasília - UnB \\ Mestre em Direitos Humanos pela Universidade Federal do Pará - UFPA \\ Instituição: Universidade do Estado de Mato Grosso - Unemat \\ Endereço: Avenida Tancredo Neves, n. 1095, Bairro Cavalhada III \\ Cep 78217-900 - Cáceres - MT PABX +55 (65) 3221-0000 \\ E-mail: prof.marielequinteiro@gmail.com
}

\author{
Rogério Quinteiro Barcellos \\ Especialista em Segurança Pública pela Academia de Polícia Militar Costa Verde - APMCV \\ Tenente Coronel do Corpo de Bombeiros Militar de Mato Grosso \\ Instituição: Corpo de Bombeiros de Mato Grosso - CBMMT \\ Endereço: Rua Coronel Benedito Leite, n. 401, Bairro Centro Sul \\ cep 78020 - 110 - Cuiabá-MT
}

\begin{abstract}
In the socio-economic-cultural context in which the Lucas do Rio Verde Municipality is inserted, to talk about the dignity of the human being is to have a dialectic discussion that visits many areas of knowledge, but that can only be understood when related to the reality in which the Municipality is inserted. The phenomenon that occurs in the Lucas do Rio Verde - MT municipality, which has one of the best human development indexes in Brazil and astonishing economic growth, is the starting point for relating the category of human dignity to the environment. This is because in the case of the Municipality of Lucas do Rio Verde - MT environmental issues and social issues are so intertwined that dealing with the environment is the outcome of a discussion about the dignity of the human person. And when it comes to this Fundamental Right, so recognized by the Brazilian Federal Constitution, it covers not only the simple survival but also a dignified survival, that is, it is the guarantee that the human being can enjoy a dignified life. The contradictions presented by the Municipality of Lucas do Rio Verde - MT, are the starting point to verify that the development that emerged after the Second World War starts to be questioned because, instead of finding autonomy with individual emancipation, we found anonymity. Instead of secularization finding freedom from religious dogma, it has brought the loss of human foundations. In this context, it can be seen that economic development cannot prosper alone, under penalty of damaging the environment and affecting the dignity of the human being to such an extent that the human being, the protagonist of this development, is robbed of the possibility of enjoying a dignified life. The dignity of the human person is an inherent human principle that must always be analyzed in an empirical and real context. It is necessary to analyze a context, with all perspectives, to contemplate the most varied facets of the dignity of the human person. In the exemplary case of Lucas do Rio Verde - MT, it was verified that the violation of the environment brutally affects the dignity of the human being. Through this unit of analysis, which is the Municipality of Lucas do Rio Verde - MT, it is possible to verify that the environment and the dignity of the human being are related, making it possible to discuss Democracy and Human Rights.
\end{abstract}

Keywords: Contradictions, Relationship, Dignity, Environment. 


\section{INTRODUCTION}

The phenomenon that occurs in the Lucas do Rio Verde - MT municipality, which has one of the best human development indexes in Brazil and astonishing economic growth, is the starting point for relating the category of human dignity to the environment.

This is because in the case of the Municipality of Lucas do Rio Verde - MT environmental issues and social issues are so intertwined that dealing with the environment is the outcome of a discussion about the dignity of the human person. And, when it comes to this Fundamental Right, so recognized by the Brazilian Federal Constitution, it covers not only the simple survival, but also a dignified survival, that is, it is the guarantee that the human being can enjoy a dignified life.

\section{VIOLATIONS TO THE ENVIRONMENT IN LUCAS DO RIO VERDE: A QUESTION OF DEPARTURE}

An important phenomenon happens in the Municipality of Lucas do Rio Verde-MT: it has reached high productivity rates and continues to exhibit high Human Development Indexes - HDI with higher degrees of development of living conditions and income (IBGE, 2010). Lucas do Rio Verde - MT is the first Green Municipality in the country. Title granted by TNC - The Nature Conservancy, which calls itself "the largest environmental conservation organization in the world" (TNC).

A project developed by TNC - The Nature Conservancy and the Lucas do Rio Verde City Hall in partnership with the State Environmental Office (Sema), the State Attorney General's Office (PGE), Rio Verde Foundation, Rural Union of Lucas do Rio Verde, State Public Ministry, Syngenta, Sadia Sustainability Institute, Sadia and Friagril called "Agribusiness and Sustainability: Lucas do Rio Verde Legal", also called "Lucas Legal", sought to combine agriculture and environmental conservation.

The main objective of the project is to eliminate environmental, health, and labor liabilities in the agricultural and livestock activity, and to allow the products to be tracked and to have free access to the most demanding markets in the world (Sustainability Compendium).

Through this, Lucas do Rio Verde became the first municipality with a complete mapping of all rural properties. It is the first in the country to have all properties regularized according to the Forest Code (TNC). The city was highlighted in the first edition of the "Brazil Environment Prize", in 2007, promoted by JB Ecológico Magazine, in partnership with Gazeta Mercantil and Forbes Brasil Magazine.

The participants of this project celebrate the result, stating that "Lucas do Rio Verde is the demonstration that economic growth and environmental respect are not irreconcilable.

It is important to highlight that the city of Lucas do Rio Verde/MT was highlighted in the last Conference held by the United Nations Organization - UN, the RIO+20, with the case presented during 
the Food Security Panel by the vice-president of the Mato Grosso Corn and Soybean Producers Association - APROSOJA/MT, with a demonstration of how the municipality has been able to combine agricultural production with socio-economic development, considering that it has reached eighth place among the Brazilian cities with the best Human Development Index - HDI. The emphasis was on the social and economic revolution in the area brought about by agribusiness. In 2012, the municipality had 57,000 (fifty-seven thousand) inhabitants, in the 2012 harvest, it produced 1.6 million tons of soybeans, processed 600,000 (six hundred thousand) liters of biodiesel per day, and has an industrial park with the capacity to slaughter 375,000 (three hundred seventy-five thousand) chickens per day and 5,000 (five thousand) pigs.

In partnership with the City Hall of Lucas do Rio Verde/MT, Syngenta, Fiagril, Sadia, Sadia Sustainability Institute, Rural Union of Lucas do Rio Verde, Rio Verde Foundation, Public Ministry and Sema, The Nature Conservancy - TNC launched a project entitled "Agribusiness and Sustainability: Lucas do Rio Verde Legal", intending to turn Lucas do Rio Verde into the first Green Municipality in the country, making it the first municipality with a complete mapping of all rural properties.

The result of the project was achieved with the legalization of all the rural properties in the municipality. Due to the results achieved by the Project, Lucas do Rio Verde/MT has become a model to be followed in other regions of the country.

The municipality was making large investments, in the face of which it is possible to make an analysis that immediately reflects on Human Rights. For example, the Lucas do Rio Verde New Industrial Unit Cold Storage Complex, which includes a poultry and pork slaughterhouse and a factory for industrialized products. It is one of the great highlights among investors in the region because it is a reference in the Brazilian market concerning technological processes, which are the most advanced in the world. The company is a member of the "Lucas do Rio Verde Legal" Project.

The company affirms to be a reference in the country in the adoption of sustainability principles, besides considering its commitment to the environment and the involvement with the community and the public that is under the investment's coverage area.

The labor force offered in the Municipality does not meet all the demand offered by the plant. The unit has 3,800 (three thousand and eight hundred) employees, of these 2,800 (two thousand and eight hundred) come from the Northeast region of the country. It has been verified that the population living in the region is taken for the supply of labor for the development of the large investments of the big companies, as is the case of Sadia. An example of this is the Project implemented in the city by the Sadia Institute, called "Sowing Education". The project announces "the implementation of environmental education in schools for children from the 4th year of elementary school and the 1st year of high school. 
The action is summarized in the installation of a seedling nursery in the Horto Florestal and the reforestation of degraded urban areas.

It is easy to see that this is about the qualification of labor to serve in agribusiness in the future and to diminish the environmental impacts caused by the expansion of agribusiness.

Although it presents itself as a reference in sustainability, the facts demonstrate the distance that exists between discourse and practice. As an example of these contradictions, the aforementioned company was sued by the State Public Ministry under the accusation of Social Dumping in Lucas do Rio Verde-MT, having to pay R \$ 3 Million in damages for Collective Moral Damages.

In addition to the above-mentioned Condemnation, another accusation made national news involving the same company. In João Pessoa, in the state of Paraíba, on the television network "Record News Nordeste" workers made accusations that the company Sadia S.A. was making misleading promises of work by offering jobs in Lucas do Rio Verde - MT.

Due to illusory promise of work, the company Sadia S/A was condemned by the Second Panel of the Regional Labor Court of Paraiba to pay compensation for moral damages for $\mathrm{R} \$ 40,000.00$ (forty thousand reais) after promising attractive working conditions to an employee that, after a certain period, proved to be degrading. In the records, it was proven that the company made illusory promises, generating damage to the worker.

In the case records, it was proven that the company made illusory promises, generating losses for the worker.

Another millionaire investment that deserves to be highlighted is the company Amaggi, which has a soybean crushing industry and one of its warehouses is located in the city of Lucas do Rio Verde-MT.

As pointed out, on the other side of the "progress" brought by agribusiness, some human rights violations can be pointed out. Arruda (2013) found the presence of slave labor on properties located in municipalities based on modernized agriculture and cattle ranching, such as Nova Mutum, Rondonópolis, Campo Novo do Paris, and Lucas do Rio Verde. It is precisely the sector that deforests the most for the (re)dimensioned agribusiness frontier. This reality was preponderant in the 1970s, preparing a priori the "terrain" for the expansion of soy and cotton, that is, for the consolidation of the current agribusiness frontier.

The same author verified that a contradictory and dialectic reality is built in the commodityproducing regions, because at the same time that living labor is replaced by dead labor, that is, the unskilled worker is absent in the operation of state-of-the-art machinery in precision agriculture, the same is present through pre-capitalist labor relations for the performance of activities that the machine cannot perform. In this sense, we share Soja's (1993) assertion when he ponders that, in face of the growing limits 
resulting from the reduction in the length of the workday, of minimum wage levels, of the conquests of the working class organization, etc., capitalism shifts with an increasing emphasis toward the extraction of relative surplus-value. This occurs through technological changes, modifications in the organic composition of capital, net transfers of surplus associated with the penetration of capital into not entirely capitalist spheres of production. This has required the construction of total systems to guarantee and regulate the reproduction of the social relations of production.

Furthermore, it was found that among the various impacts of the agribusiness production chain, the most relevant for health and the environment are the acute and chronic pollution and poisoning related to pesticides. In this agrochemical process, farmers contaminate the crop, the product, the environment, the farmworkers, and the surrounding population to reach the target or crop pests.

It is important to highlight that the use of pesticides began to be widespread after World War II, where they were used as chemical weapons. After that, it began to be used in agriculture, with promises of increased production and conditioning it to the use of efficient technologies in pest control. (DAS NEVES, 2015)

Mato Grosso has 141 municipalities, 54 of which have similar agricultural production processes. In the state, between the years 2007 and 2010, research coordinated by Professor Doctor of Medicine of the Federal University of Mato Grosso, Wanderlei Antonio Pignatti39, entitled "Impact of Agrotoxics on health and the environment in the municipalities of the interior of Mato Grosso, Brazil" was carried out, which investigated the impacts of agribusiness in the Midwest region.

By sampling, the research chose the cities of Lucas to do Rio Verde/MT and Campo Verde/MT as representatives for researching the impacts of pesticides on health and the environment. The data and samples were collected, analyzed, and showed similar data in both municipalities. In this paper, some conclusions reached by that research on the impact of agribusiness on health and the environment in Lucas do Rio Verde/MT (PIGNATI, 2014) will be reported.

In 2010, Lucas do Rio Verde/MT had 37,000 (thirty-seven thousand) inhabitants and a Human Development Index - HDI of 0.818, i.e., the third best HDI in the state. Even consuming 5.1 million liters of pesticides to sustain the 420,000 (four hundred and twenty thousand) hectares between soybeans, corn, and cotton (PIGNATI, 2014).

Given this scenario, FIOCRUZ in partnership with UFMT had the partnership of 04 urban and rural schools, located in the city of Lucas do Rio Verde/MT, to collect data related to the impact of agribusiness in the city. The data collected showed what follows below:

I - Environmental/occupational/food exposure of 136 liters of pesticides per inhabitant during 2010; 
II - The agrochemical spraying by airplane and tractor was carried out within 10 meters from sources of drinking water and animal husbandry and from residences.

III - Contamination of residues of various types of pesticides in $83 \%$ of drinking water wells (schools and cities) and contamination with pesticides of $56 \%$ of rain samples (schoolyards) and of $25 \%$ of air samples (schoolyards monitored for 02 years).

V - Contamination with pesticide residues (DDE, Endosulfan, Deltamethrin and DDT) in 100\% of the samples of breast milk of sixty-two (62) mothers who breastfed, in 2010, in the city

VI - Presence of residues of various types of pesticides in sediments of two ponds, similar to the types of residues found in the blood of frogs, with a high incidence of congenital malformation in these animals. Another study also showed that glyphosate exposure in earthworms causes malformations and deaths of the species.

VII - The incidences of correlated diseases (work accidents, intoxications, cancers, malformations, and respiratory diseases) have increased between $40 \%$ and $102 \%$ in the last 10 years, with a level $50 \%$ above the statewide incidence in these years. It was verified that, in the state, the highest incidences are in the regions of Sinop, Tangará da Serra and Rondonópolis.

The research has shown that to maintain that human and environmental productive effort imposed by agribusiness there are gaps in social control and gaps in public oversight. The population of the interior of Mato Grosso lives with pesticide pollution and is a victim of health problems, environmental damage, and pollution of the Amazon and Araguaia River basins (PIGNATI, 2014).

This UFMT action research in partnership with FIOCRUZ started the popular movement called "The pesticide rain on the urban area of Lucas do Rio Verde" (PIGNATI, 2014).

Nowadays, the use of these substances has led to several problems, related, in particular, to environmental contamination and public health. Brazil has gradually become one of the largest consumers of pesticides, with a large number of potential rural workers exposed to significant amounts of these products. (DAS NEVES, 2015)

Arruda (2013) conducted interviews in the municipalities of Nova Mutum and Lucas do Rio Verde with the presidents of the rural workers' unions and obtained information that in recent times most of the members were small landowners in the region, but today salaried workers from large farms prevail in the local union ranks. This fact, by itself, demonstrates the advance of proletarianization or wage-earning in the Mato Grosso countryside. At the same time, the capitalized investor is attracted by the possibility of extracting profit from the land and collaborates unsatisfactorily in the regional economic growth when he leaves a derisory portion of the profits through the salaries of his employees and taxes. The situation is aggravated by the poor performance of the public power, which, fascinated by the agribusiness figures, 
deceives the population by alleging the benefits to be gained by the implantation of agribusiness enterprises. Besides the hegemonic argument of agribusiness developmentalism, there is the discourse that the operation of economic activities in productive chains and large properties can reduce deforestation by reducing the pressure for new areas for the expansion of grain cultivation.

Given this scenario, Beck (1992) states that the industrialization process is associated with the risk production process. The main consequence of scientific industrial development is the exposure of humanity to risks and numerous forms of contamination, never before observed, constituting threats to the inhabitants and the environment. And it is not only the current population that is exposed to these risks; future generations are even more seriously affected.

To point out the contradictions above, no arbitrary or dogmatic premises were analyzed. The picture that is presented in Lucas do Rio Verde - MT is real premises. "They are the real individuals, their action and their material conditions of life, both those they encountered and those they produced with their action. These premises, therefore, verifiable in a purely empirical way" (MARX, 2009).

Given this real and dialectical movement found in Lucas do Rio Verde-MT it is possible to identify the relationship between the category human dignity and the relationship with the environment.

\section{THE CATEGORY OF HUMAN DIGNITY AND ITS RELATION TO THE ENVIRONMENT}

Reality is not immediately known, it is complex and presents itself in multiple facets, and it is not made known in a conventional empirical investigation. It is necessary to record facts and catch relationships so that the research does not remain in appearances (IANNI, 2011).

And, in the socio-economic-cultural context in which the Lucas do Rio Verde Municipality is inserted, to talk about the dignity of the human being is to have a dialectic discussion that visits many areas of knowledge, but that can only be understood when related to the reality in which the human being is inserted.

The realization of human dignity requires the effective guarantee of many rights, among them equality, freedom, honor, privacy, and all the social rights brought by the Brazilian Federal Constitution. The realization of all these rights seeks the outcome that the human person can enjoy a life of dignity.

The right to a life with dignity is immediately related to the right to an ecologically balanced environment, according to the Inter-American Covenant on Economic, Social, and Cultural Rights of 1966, when human rights became a priority in international law.

This relationship is the result of historical evolution, with two milestones worth highlighting: World War II, which brought the need for the recognition of Human Rights (Terezo), and the Report entitled "The Limits of Growth", prepared by scientists at the Massachusetts Institute of Technology, 
which stated that with the maintenance of human conduct, the world would be devastated by the middle of the 21st century (LEAL and MARTINAZZO, 2012, p. 45).

The Second World War was marked by the sacrifice of Poles and Russians, the persecution of Jews, and American nuclear bombs, and its end presented a new phase of capitalism. A new international division of labor was formulated, goods, people, and capital were trans nationalized, and international economic activities expanded. There was a new design of the world economy that brought new social demands, bringing in its wake the emergence of the Law of Peoples and the Law of All Humanity. This new demand put aside the search for individual rights, but intended the protection of the whole society, seeking joint efforts of the state and society (TEREZO, 2011).

Terezo (2011) says that this new scenario, together with issues such as the maintenance of peace and international security, the development of equal rights relations among nations, international cooperation to solve economic, social, and cultural problems, and the need to enforce respect for human rights, gave rise to and consolidated the Global Human Rights System, through the United Nations (UN).

It can be seen that the first objective of the United Nations Global System was to punish the horrors of war and to prevent, prevent that the fundamental rights of the human person could ever again be so disrespected.

However, with the publication of the report entitled "The Limits of Growth", the world's concerns about what happened in the Second World War became secondary in the face of the horrors that were to come and strike all of humanity if environmental derangement continued at a rate capable of devastating human survival on Earth.

With the Global Human Rights System already in place, through the United Nations, the main concern became the preservation of the environment, which was not well received by developing countries with the justification of slowing down economic growth. As an alternative, scholars have developed a new solution called Sustainable Development, which, in summary, claims that the ecologically balanced environment and economic development can coexist harmoniously.

Because it is a concept that is still under construction, the United Nations Organization - UN presented some indicators that must be met by all economic activity to ensure sustainable development, namely, economic indicator, social indicator, and environmental indicator.

This construction arose for a single reason, so that man can enjoy a dignified life, that is, to guarantee the dignity of the human person.

And the Municipality of Lucas do Rio Verde - MT when inserted in this context demonstrates that the non-recognition, the non-implementation of sustainable development immediately affects the dignity of the human being. 
Boff (2003) verified that contemporary society is going through a paradigm crisis, the crisis of the greatest dream that gave meaning to the modern world: unlimited development, the will to power as domination. It is this modern rationality that has caused water contamination, soil poisoning, the massive urbanization of ecologically fragile regions, acid rain, harmful waste dumping, desertification, erosion, deforestation, soil salinization, floods, carbon gas emissions that intensify the greenhouse effect, and the gradual decomposition of the ozone layer.

In the same sense as Beck's (2010) considerations, Boff (2003) concluded that the paradigm of the modernity model has put at risk the most precious and fundamental existing good: the perpetuation of life and, paradoxically, the very human existence of the earth.

It is important to add the words of the Secretary-General of the United Nations, Ban Ki-Moon, in Davos in January 2011, which demonstrates the direct relationship between the environment and human dignity, and which fits perfectly to the case of Lucas do Rio Verde - MT: "the current world economic model is a global suicide pact. (ABRAMOVAY, 2012).

\section{FINALS CONSIDERATIONS}

The contradictions presented by the Municipality of Lucas do Rio Verde - MT, are the starting point to verify that the development that emerged after the Second World War starts to be questioned because, instead of finding autonomy with individual emancipation, we found anonymity. Instead of secularization finding liberation from religious dogmas, it brought the loss of human foundations. (MORIN, 2011, p. 76, 77).

In this context, we can conclude that economic development cannot prosper alone, under penalty of damaging the environment and affecting the dignity of the human being to such an extent that the human being, the protagonist of this development, is robbed of the possibility of enjoying a dignified life.

As stated above, human dignity is an inherent human principle that should always be analyzed in an empirical and real context. It is necessary to analyze a context, with all perspectives, to contemplate the most varied facets of human dignity. In the exemplary case of Lucas do Rio Verde - MT, it was verified that the violation of the environment brutally affects the dignity of the human being.

Finally, it is important to point out that the Lucas do Rio Verde - MT municipality is only a unit of analysis to demonstrate how the environment and human dignity are related.] 


\section{REFERENCES}

ABRAMOVAY, Ricardo. Far beyond the green economy. Editora Abril, 2012.

ARRUDA, Zuleika Alves de. Cities in the region of agribusiness expansion and new territorialities. Federal Institute of Education, Science and Technology of Mato Grosso. Major in Geography. Revista Territorium TerraM, V.01, nº 01, p. 72-94. Out/Mar-2012/2013.

BECK, Ulrich. Risk Society: towards another modernity. São Paulo: Editora 34, 2010.

BOFF, Leonardo. The land option: the solution for the land does not fall from the sky. Rio de Janeiro: Editora Record, 2009.

DAS NEVES, Cleuler Barbosa; ABREU, Natasha Gomes Moreira; GAMA, Thiago Venâncio Noleto da. RURAL WORKER AND EXPOSURE TO PESTICIDES: HEALTH RISKS, VIOLATION OF HUMAN RIGHTS, AND THE RIGHT TO ADDITIONAL UNHEALTHY SALARY. In: XIII WORLD CONGRESS ON AGRICULTURAL LAW: Challenges of Contemporary Agrarian Law 2014, Ribeirão PretoSP. Anais. 1 ${ }^{\text {a }}$ Edição. Altai Edições. Ribeirão Preto, 2014.

IANNI, Octávio. " The construction of the category." Revista HISTEDBR On-Line 11.41e (2011).

IBGE - Brazilian Institute for Research and Statistics. Available at: <http://www.ibge.gov.br/home/> Acesso em: 29 de maio de 2015.

LEAL, Carla Reita Faria e MARTINAZZO, Waleska Malvina Piovan. The use of sustainability and environmental law principles to realize environmental rule of law. IN: Environmental Law and Sustainability: challenges for the legal protection of sociobiodiversity. / Patryck de Araújo Ayala../ Curitiba: Juruá, 2012. p. 39)

MARX, Karl, and Friedrich Engels. The economic and philosophic manuscripts of 1844 and the Communist manifesto. Prometheus Books, 2009.

MORIN, Edgar e KERN, Anne Brigitte. Terra Pátria. 6ª ed. Editora Sulina, 2011

PIGNATI, WANDERLEI. Resumo executivo. 2014

TEREZO, Cristina Figueiredo. " The actions of the Inter-American system for the protection of human rights in the defense of economic, social and cultural rights." (2011).

TONET, I. " Scientific Method." An ontological approach. São Paulo: Lukács Institute (2014). 